\title{
Dendroecology in the tropics: a review
}

\author{
Danaë M. A. Rozendaal · Pieter A. Zuidema
}

Received: 25 January 2010/Revised: 15 July 2010/Accepted: 28 July 2010/Published online: 31 August 2010

(C) The Author(s) 2010. This article is published with open access at Springerlink.com

\begin{abstract}
Over the last decade the field of tropical dendroecology has developed rapidly and major achievements have been made. We reviewed the advances in three main themes within the field. First, long chronologies for tropical tree species were constructed which allowed climate reconstructions, revealed sources of climatic variation and clarified climate-growth relations. Other studies combined tree-ring data and stable isotope $\left({ }^{13} \mathrm{C}\right.$ and $\left.{ }^{18} \mathrm{O}\right)$ measurements to evaluate the response of tropical trees to climatic variation and changes. A second set of studies assessed long-term growth patterns of individual trees throughout their life. These studies enhanced the understanding of growth trajectories to the canopy, quantified autocorrelated tree growth and yielded new estimates of tree ages. Such studies were also used to reconstruct the disturbance history of tropical forests. The last set of studies applied tree-ring data to growth models. Tree-ring data can replace diameter
\end{abstract}

Communicated by A. Bräuning.

Contribution to the special issue "Tropical Dendroecology".

D. M. A. Rozendaal · P. A. Zuidema

Ecology and Biodiversity, Institute of Environmental Biology,

Faculty of Science, Utrecht University, Padualaan 8,

$3584 \mathrm{CH}$ Utrecht, The Netherlands

D. M. A. Rozendaal · P. A. Zuidema

Programa Manejo de Bosques de la Amazonía Boliviana (PROMAB), Universidad Autónoma de Beni (UAB),

P. O. Box 107, Riberalta, Bolivia

Present Address:

D. M. A. Rozendaal ( $\square)$

Department of Forestry, Michigan State University,

126 Natural Resources Building, East Lansing,

MI 48824-1222, USA

e-mail: rozendaa@msu.edu; danaerozendaal@hotmail.com measurements from research plots, provide additional information to construct population models, improve timber yield models and validate model output. Based on our review, we propose two main directions for future research. (1) An evaluation of the causes and consequences of growth variation within and among trees and their relation to environmental variation. Studies evaluating this directly contribute to improved understanding of tropical tree ecology. (2) The simultaneous measurement of widths and stable isotope fractions in tree rings offers the potential to study responses of trees to climatic change. Given the major role of tropical forests in the global carbon cycle, knowing these responses is of high priority.

Keywords Tree rings - Climate-growth relations . Tropical forest dynamics - Long-term growth patterns . Tree age $\cdot$ Growth modelling

\section{Introduction}

The occurrence of annual growth rings in the tropics has been denied for a long time (e.g. Lieberman et al. 1985). The absence of annual growth rings was thought to be a consequence of a lack of clear seasonality in the humid tropics. Yet, as early as 1927 the existence of annual growth rings in tropical trees had been described (Coster 1927). Since then it has become clear that annual rings are formed when tropical trees experience cambial dormancy in one period of the year due to unfavourable environmental conditions. Such a period can be the dry season in areas with distinct seasonality (e.g. Worbes 1999) and flooding periods in floodplain forests (e.g. Schöngart et al. 2002) and fluctuations in salinity in mangrove forests due to seasonality in precipitation and temperature (Chowdhury 
et al. 2008). As seasonally dry forests, floodplain forests, and mangroves cover large part of the total tropical forest area, there is a large potential for the application of treering analysis in the tropics. Even in evergreen forests successful tree-ring studies have been conducted in areas were a short dry period triggers annual ring formation (e.g. Dünisch et al. 2003; Fichtler et al. 2003).

Tropical tree-ring boundaries are often anatomically less distinct and sometimes less reliable than those in temperate zones (Worbes 2002). Climatic fluctuations within the seasons can cause formation of false rings (Priya and Bhat 1998), wedging rings are common (Worbes 2002), and also non-annual ring formation has been shown (Dünisch et al. 2003; Wils et al. 2009). Hence, the annual nature of the rings needs to be proven before tree-ring studies can be conducted. Over the last decades, the annual character of tree rings has been established for a large number of species in many tropical areas (e.g. Worbes 2002; Dezzeo et al. 2003; Brienen and Zuidema 2005), thus providing a sound basis for applying tree-ring analysis to tackle ecological questions.

In temperate zones, tree-ring analysis has provided a major contribution to the understanding of tree ecology, forest dynamics and climate-growth relations of trees. In the tropics the potential contribution of dendroecological studies may likewise be large, because there is a clear need for reliable age estimates (Martínez-Ramos and AlvarezBuylla 1998; Worbes 2002), long-term tree growth data (Ashton 1981) and information on tree recruitment patterns. Such data are needed to provide insights into tropical forest ecology, to guide forest management and conservation practices and to evaluate the impacts of climate change on these forests.

Over the last decade, the field of tropical dendroecology has developed rapidly. Interesting ecological insights have been obtained from studies in this field, and important methodological advances have been made. For instance, the combination of tree-ring analysis with determination of stable isotope fractions in wood tissue offers new ways to reconstruct historical growing conditions of trees and understand their physiological responses to changing conditions. Also, tropical tree-ring data have been used to construct and validate tree growth models and population models.

Since the review of tropical tree-ring research by Worbes (2002) a large number of new studies has been published, many of which have yielded new ecological insights. Thus, the rapid development of this field asks for a review of recent achievements. Here we discuss recent findings from tropical dendroecology studies and provide an outlook to future challenges in this field. First, we briefly refer to the methodology in tropical tree-ring research. Then, we discuss eight themes that are of relevance from an ecological viewpoint. For each of these themes we discuss the new ecological insights that tropical tree-ring studies have contributed so far.

\section{Periodicity in tree growth and detection of tropical tree rings}

In most tropical areas seasonal changes in environmental conditions are less pronounced than in temperate forests. As a result, the periodicity in tree growth needs to be evaluated to prove annual ring formation and field sampling strategies need to be adjusted. Due to the presence of wedging rings, working with stem discs rather than increment cores is generally recommended (Worbes 2002). This implies that sampling may be confined to logged areas or to trees that died naturally. However, for some tree species measuring ring widths from increment cores has been successful.

Numerous techniques have been proposed and applied to evaluate the annual nature of tropical tree rings. While the aim of this review is not to extensively describe and discuss these techniques, we briefly mention them. A first technique to evaluate the annual character of ring formation involves measuring the periodicity of tree growth through dendrometer measurements (Bräuning et al. 2009; Krepkowski et al. 2010; Volland-Voigt et al. 2010). By measuring stem diameter increase and shrinkage over the seasons, insight in intra-annual growth dynamics can be obtained. Periodicity in tree growth can also be evaluated by looking at anatomical changes after cambial wounding, and counting the number of rings after pinning the cambium (e.g. Lisi et al. 2008). A second method is radiocarbon dating. Nuclear tests in the 1960s increased the level of ${ }^{14} \mathrm{C}$ in atmospheric $\mathrm{CO}_{2}$, allowing the possibility to rather precisely date trees of $<50$ years old (e.g. Worbes and Junk 1989; Hua et al. 1999). This method has been applied in various studies and may assist in the anatomical recognition of ring boundaries (Fichtler et al. 2003; SolizGamboa et al. 2010). Third, ring widths of trees from a population can be cross-dated, to assess whether synchronous ring formation occurs, which allows relating tree growth to climatic variables (e.g. Wils et al. 2010). For various tree species annual ring formation has been shown through correlating growth with rainfall (e.g. Couralet et al. 2005; Baker et al. 2008). In mangroves in particular, evaluating annual periodicity in tree growth and relating growth to climatic variables can be challenging, as multiple factors have been shown to influence growth (Robert et al. this issue). For the mangrove species Rhizophora mucronata annual ring formation has been shown using cambial wounding (Verheyden et al. 2004).

Finally, there are a number of methods that have been proposed to detect rings for tree species that do not form 
distinguishable ring boundaries. Many of these methods are still in a rather experimental phase, but often with promising results. For instance, periodicity in tree growth has been shown by evaluating the periodicity in vessel density for a mangrove species (Verheyden et al. 2005). Similarly, intra-annual fluctuations in stable isotope concentrations have been evaluated, which indicated periodicity in tree growth (Poussart et al. 2004; Anchukaitis et al. 2008; Ohashi et al. 2009; Pons and Helle this issue).

\section{Climate-growth relations}

For numerous species it has been shown that tree radial growth is influenced by climatic factors (Fig. 1). Through identifying the common, temporal growth pattern in a population of trees and relating this pattern to rainfall data, species-specific responses to rainfall can be determined. Seasonally dry forest species respond to rainfall in different ways (Fig. 1). Tree species have been shown to respond to total annual rainfall, total rainfall in the rainy season, rainfall in the dry season, rainfall in the transition and a relation between growth and rainfall in the previous year has been found (Fig. 1). These species-specific responses may reflect differences in growth strategies among species (cf. Enquist and Leffler 2001; Couralet et al. 2010). Also negative correlations between growth and rainfall have been reported (e.g. Buckley et al. 2007; Soliz-Gamboa et al. 2010), which may indicate a response to higher light levels due to low cloud cover. Most studies report correlations between growth and rainfall, as temperature shows in general little interannual variation in tropical areas. For some species, nevertheless, a correlation was found between both growth and temperature and growth and precipitation (e.g. Trouet et al. 2001; Buckley et al. 2007; López and Villalba 2010). In Amazonian floodplain forests tree growth was found to be correlated with the water level in the non-flooded period (Dezzeo et al. 2003), or with the length of the non-flooded phase (Schöngart et al. 2005).

Climatic conditions may not only be driving tree growth, but could also influence tropical forest dynamics. In tropical pine forests in northern Thailand, the relation between climatic variability and recruitment was evaluated using tree-ring analysis for two Pinus species (Zimmer and Baker 2009). Although recruitment was not directly related to climate, periods of several years of cool and wet conditions were associated with enhanced recruitment. These results indicate that climate may influence patterns of tree establishment (Zimmer and Baker 2009).

The existence of a relationship between growth and precipitation provides the possibility to reconstruct historical precipitation patterns. Because the meteorological records of precipitation in the tropics do rarely span more than a few decades, tree-ring based climate reconstructions may strongly enhance our insights about historical climate. By now, several long chronologies have been established, varying from a length of 150-200 years for some species (Schöngart et al. 2006; Therrell et al. 2006; Sass-Klaassen et al. 2008), to almost 400 years for Macrolobium acaciifolium in an Amazonian black-water floodplain forest (Schöngart et al. 2005). Apart from responding to rainfall and temperature, trees also respond to larger-scale climatic fluctuations such as the El Niño Southern Oscillation (ENSO; e.g. Schöngart et al. 2004; Rodríguez et al. 2005; Therrell et al. 2006; Gebrekirstos et al. 2008). As climate reconstructions have been reported now for tropical Africa, South America, and Asia, large-scale climatic fluctuations can be identified. The reconstructed climatic fluctuations in the Central Amazon could be largely recognized in African forests as well (Schöngart et al. 2006). In general, a trend towards drier conditions in more recent times has been observed. Increasing aridity has been observed in West Africa over the last 160 years (Schöngart et al. 2006) and also in Amazonia the frequency of El Niño-induced droughts increased over the last two centuries (Schöngart et al. 2004).

The recent development of the Monsoon Asia Drought Atlas (MADA) by Cook et al. (2010) is a major step forward in the application of tree rings to the reconstruction of tropical climates. Their reconstruction of monsoon variability across Asia is based on $>300$ tree-ring chronologies from temperate, sub-tropical, and tropical Asian sites and provides an annually resolved, spatially explicit record of drought intensity over the past 1,000 years. The MADA provides a unique record of climate variability that can be compared to long-term records of sea surface temperature, ENSO, and other major drivers of regional climate variability. One of the key features of the monsoon variability that the MADA has identified is the occurrence of several intense, multi-decade droughts over the past millennium. Through reconstructing climate fluctuations in the past, it is possible to predict the response of tropical trees to future climatic change. For a Mexican dry forest tree species, for example, a growth decline ranging from 12 to $21 \%$ was predicted for the end of this century (Brienen et al. 2010a).

\section{Pathways to the canopy}

How do tropical trees grow to the canopy? Growth trajectories of canopy trees have been reconstructed with treering analysis to tackle this question, and have revealed large variation in the way in which trees attain the canopy both among and within species (Baker and Bunyavejchewin 2006; Brienen and Zuidema 2006a). Many researchers have hypothesized that juvenile trees of canopy species 
Fig. 1 Overview of observed climate-growth relations for some tropical tree species in seasonally dry tropical forests with different mean annual precipitation. $x$ indicates a significant, positive correlation (Pearson's $r, P<0.05$ ) with precipitation: either total annual precipitation, the precipitation in the rainy season, precipitation in the dry season, precipitation in a transition between the seasons or total precipitation in the rainy season of the previous year. Numbers at the right part indicate the source: 1 Fichtler et al. (2004), 2 Gebrekirstos et al. (2008), 3 Trouet et al. (2006), 4 Brienen et al. (2010a), 5 Pumijumnong et al. (1995), 6 Schöngart et al. (2006), 7 SassKlaassen et al. (2008), 8 Enquist and Leffler (2001), 9 Brienen and Zuidema (2005), 10 Worbes (1999), 11 Zuidema et al. (2010), 12 Dünisch et al. (2003)

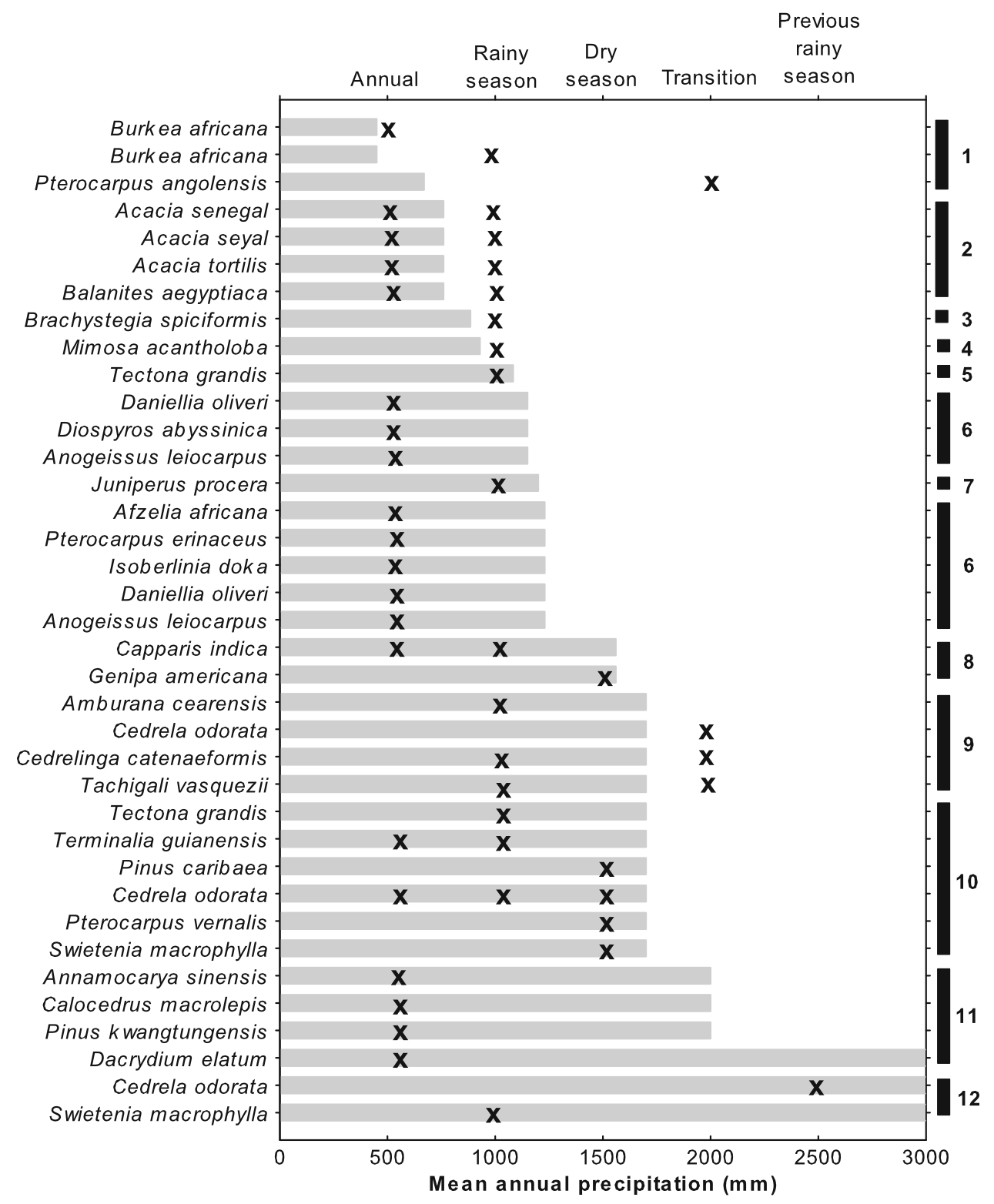

would require at least one gap event to reach the canopy (e.g. Turner 2001). Brienen and Zuidema (2006a) indeed found that trees of four non-pioneer species experienced on average 0.8-1.4 releases before attaining the canopy. Species differed in growth patterns towards the canopy, which suggests that the four non-pioneer species differ in shade tolerance (Brienen and Zuidema 2006a). Similarly, Baker and Bunyavejchewin (2006) found large differences in canopy accession patterns among species in a seasonal tropical forest in Thailand. The most shade-intolerant species, Melia azedarach, reached the canopy with constant fast growth, whereas the shade-tolerant Neolitsea obtusifolia established mostly in low-light conditions and required at least one release to reach the canopy (Baker and Bunyavejchewin 2006). Importantly, they showed that almost none of the $>100$ individuals studied reached the canopy by establishing in the understorey and growing into the canopy without the presence of a gap. A third study compared canopy accession patterns in a tropical dry and moist forest for the same tree species, Cedrela odorata (Brienen et al. 2010c). In the moist forest more and stronger releases were found and a larger proportion of the juvenile trees showed suppressed growth. Thus, in the moist forest light availability may be governing canopy accession, while in dry forest, most likely, water availability is more important in determining growth patterns (Brienen et al. 2010c).

Which trees are able to attain the canopy? Most juvenile tropical trees grow slowly, as light availability in the understorey is low (Chazdon and Fetcher 1984). Because slow-growing juveniles experience higher mortality rates (Wyckoff and Clark 2002), they may have a considerably 

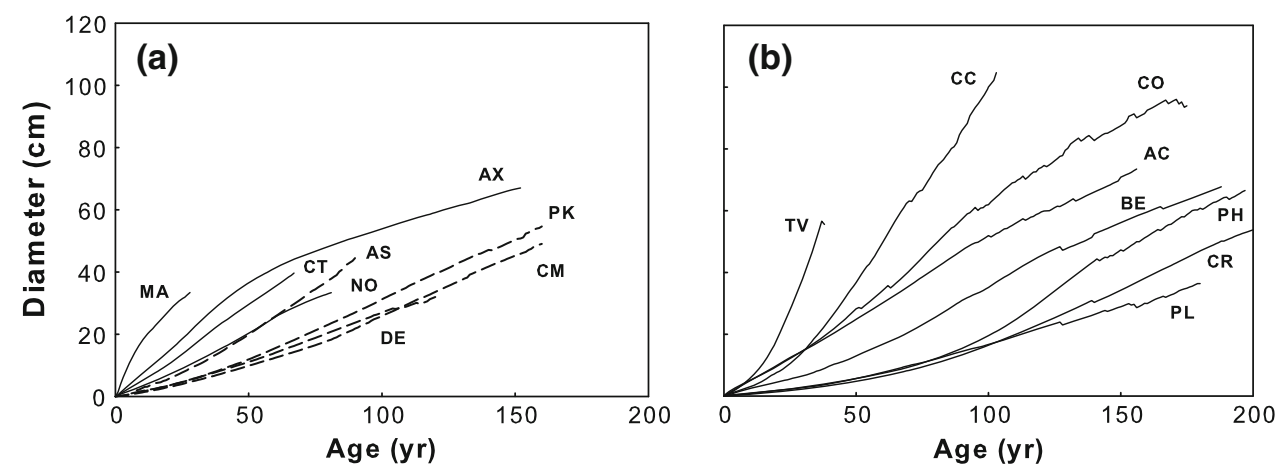

Fig. 2 Average growth-trajectories of tropical tree species from Thailand, Vietnam and Bolivia. Averages at a certain tree age were shown only if at least ten trees of a species which reached that age were included. a Tree species from Thailand (continuous lines) and Vietnam (dashed lines). Data for Melia azedarach (MA), Afzelia xylocarpa (AX), Chukrasia tabularis (CT) and Neolitsea obtusifolia (NO) are adapted from Baker et al. (2005). Data for the Vietnamese species Annamocarya sinensis (AS), Pinus kwangtungensis (PK), Calocedrus macrolepis (CM), and Dacrydium elatum (DE) are

lower chance to attain the canopy compared to the fastgrowing individuals (e.g. Enright and Hartshorn 1981). This would mean that successful trees have grown faster as juveniles, compared to juvenile trees at this moment in the forest ('juvenile selection effect'). Rozendaal et al. (2010a) compared growth rates of extant juvenile trees with growth rates of trees that made it to the canopy at the time they were young and of the same size. For three out of five species juvenile growth rates increased with extant tree size, implying that for these three species fast juvenile growth may be essential to reach the canopy.

As the number of studies reconstructing lifetime growth patterns is very limited, general patterns in growth strategies towards the canopy cannot be derived yet. However, the few studies that have been performed do show that long-term growth patterns differ strongly across the studied species (cf. Fig. 2; Baker and Bunyavejchewin 2006; Brienen and Zuidema 2006a; Zuidema et al. 2010) and across forest types (Brienen et al. 2010c). Tree-ring studies can play an important role in revealing these growth patterns.

\section{Ages of tropical trees: an age-old debate}

The report that millennia-old trees are present in the Amazon (Chambers et al. 1998), led to an intensive debate about the accuracy of different age estimation methods and the actual occurrence of such old trees (cf. Martínez-Ramos and Alvarez-Buylla 1998; Worbes and Junk 1999). Probably, the importance of very old trees for carbon cycling has been overestimated, as those trees will occur at very low densities in the forest (Martínez-Ramos and AlvarezBuylla 1998; Williamson et al. 1999). Nevertheless, also in adapted from Zuidema et al. (2010). b Bolivian tree species. Tachigali vasquezii (TV); Cedrelinga catenaeformis (CC); Cedrela odorata (CO); Amburana cearensis (AC); Bertholletia excelsa (BE); Peltogyne cf. heterophylla (PH); Clarisia racemosa (CR); Pseudolmedia laevis (PL). Data for $\mathrm{TV}, \mathrm{CC}, \mathrm{CO}, \mathrm{AC}$ and $\mathrm{BE}$ are adapted from Brienen and Zuidema (2006a), data for PH and CR are adapted from Rozendaal et al. (2010c), and data for PL are from Rozendaal (2010)

other studies some very old trees were found using ${ }^{14} \mathrm{C}$ dating (e.g. Kurokawa et al. 2003). The primary limitation of ${ }^{14} \mathrm{C}$-dating is that the atmospheric ${ }^{14} \mathrm{C}$ values for the period from 1650 to 1940 have multiple peaks with similar values making it difficult to age wood samples correctly (cf. Martínez-Ramos and Alvarez-Buylla 1998). Most canopy trees of today are likely 70-350 years old; therefore ${ }^{14} \mathrm{C}$-dating has not been widely applied in tropical ecology.

A second approach to obtain tree ages-the use of growth data from permanent sample plots-similarly resulted in very high estimates (Martínez-Ramos and Alvarez-Buylla 1998). This is likely caused by the use of average growth rates in the calculations, which implicitly assumes that both slow-growing and fast-growing trees eventually reach the canopy (cf. Laurance et al. 2004). The application of age estimation methods that use aboveaverage growth rates is justified by the recent finding of a 'juvenile selection effect' in tropical forest trees (Rozendaal et al. 2010a). Such a juvenile selection effect implies that fast-growing juveniles have higher chance of reaching the canopy compared to slow-growing juveniles in these species. Age estimations from growth models can be much improved by comparing outcomes with observed ages from tree-ring data for the same trees or tree species (Baker 2003; Brienen et al. 2006; Chien 2006). Baker (2003) developed age estimation methods for tropical trees based on such comparisons by testing them for temperate species with a varying degree of shade tolerance. Results of age projections can be improved by accounting for autocorrelated growth, which results in higher, more realistic, variation in tree ages (Brienen et al. 2006). A recent approach using plot data accounts for variation in growth 


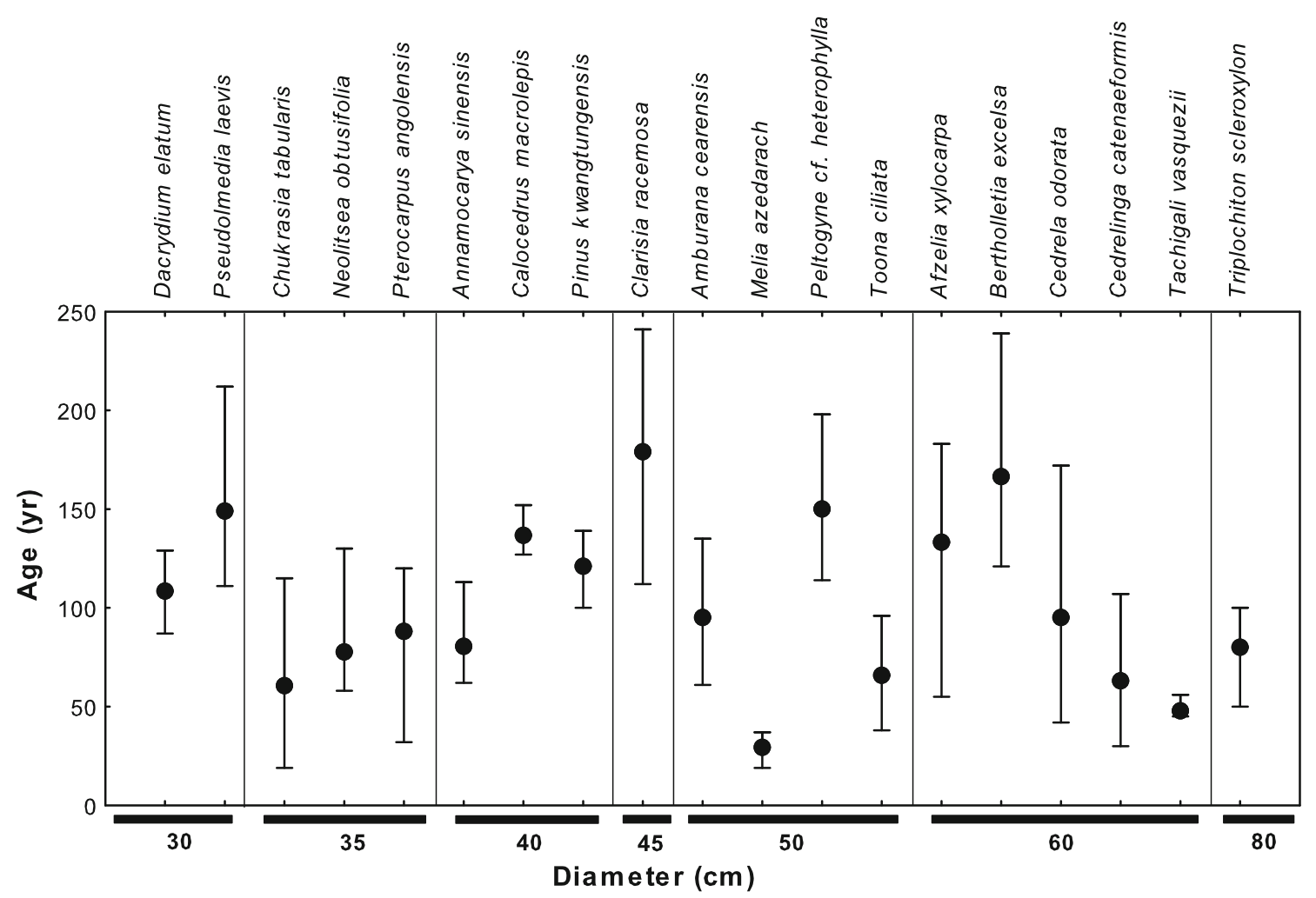

Fig. 3 Average and range in ages determined through tree-ring counts at a certain tree diameter for various tropical tree species from South America, Asia and Africa. Ages for Annamocarya, Calocedrus, Dacrydium and Pinus are obtained from Zuidema et al. (2010); for Pseudolmedia from Rozendaal (2010); for Chukrasia, Melia and Toona from C.A. Nock (unpublished data); for Neolitsea and Afzelia

by allowing autocorrelation in light levels and linking that directly to growth rates (Metcalf et al. 2009), but without an independent check of ages.

Tree-ring analysis provides a direct method for age determination and is likely the most accurate method to determine tree age (Martínez-Ramos and Alvarez-Buylla 1998). We summarized ages obtained from tree-ring counts for 19 tropical tree species (Fig. 3). Average age of the species included was 101 years, while maximum ages varied between 37 and 241 years. Although these ages were not obtained at maximum tree size, still the values are much lower than some of the estimates based on ${ }^{14} \mathrm{C}$ bomb peak dating and do probably not include trees that would reach the age of 1,000 years.

\section{Variation among trees: autocorrelation, persistent growth differences and implications}

Large variation in growth exists among individual trees of a given species in a given piece of forest. Such variation has been observed in permanent plot studies (Clark and Clark 1992) and is probably caused by differences in from Baker et al. (2005); for Pterocarpus from Stahle et al. (1999); for Clarisia, Cedrelinga and Peltogyne from Rozendaal et al. (2010c); for Amburana and Cedrela from Brienen and Zuidema (2006b); for Bertholletia and Tachigali from Brienen and Zuidema (2006a); and for Triplochiton from Worbes et al. (2003)

growth conditions among trees, in combination with temporal changes in those conditions. Altogether, this may lead to autocorrelated growth, implying that growth of a tree during one year is related to its growth in the next year, or the following, and/or that growth differences among trees are maintained over time (Brienen et al. 2006). Strong temporal autocorrelation in tree growth has been observed in permanent sample plot studies (e.g. Kammesheidt et al. 2003; Grogan and Landis 2009). Using tree-ring analysis, it is possible to detect autocorrelated growth over much longer periods than available from permanent plots.

So far, dendroecological studies have evaluated persistence of growth differences among trees for eight tropical tree species (Brienen et al. 2006, 2010c; Zuidema et al. 2010). For all species, growth differences among trees were found to persist over one to several size categories for larger trees (Table 1). Thus, fast-growing trees keep growing fast over prolonged time periods, and slowgrowing trees continue to do so over long timespans as well. Overall, these growth differences seemed to be most persistent for trees that have already grown out of the dark understorey (10-15 cm diameter; Table 1). Smaller trees in the understorey experience more switches between periods 
of suppression and release, which probably leads to lower persistence in growth differences among trees over time (Brienen et al. 2006). However, in tropical dry forest even for small trees among-tree growth differences were strongly persistent over time (Table 1; Brienen et al. 2010c). In tropical dry forest, among-tree differences in growth reflect, most likely, spatial variety in water availability. Thus, factors driving long-term growth patterns may vary among forest types (Brienen et al. 2010c).

This finding has several important implications. First, the strongly persistent differences in growth rates lead to large variation in age at a certain tree size (Fig. 3; Brienen et al. 2006). Accounting for persistent growth differences in tree growth projections leads to more realistic estimates of average and variance in tree age (Brienen et al. 2006). A second consequence of persistent growth differences is the disproportional importance of the persistent fast growers for the growth of populations. Persistently fast growing trees may boost population growth by reaching reproductive size at a young age. This has important implications not only for insights in tree demography (Zuidema et al. 2009), but also for estimating the regrowth of timber after selective logging (Brienen and Zuidema 2007).

\section{Tree growth responses to increasing atmospheric $\mathrm{CO}_{2}$}

The importance of tropical forests in the global carbon cycle has prompted considerable interest in the changes in carbon stocks in these forests. Data from permanent sample plots have shown that over the past decades aboveground biomass, tree growth and stem turnover increased (Lewis et al. 2009). Causes of these changes are strongly debated (e.g. Lewis et al. 2004; Wright 2005; Chave et al. 2008), but may be due to the increase of atmospheric $\mathrm{CO}_{2}$ (cf. Lewis et al. 2009). In temperate forest, tree-ring analysis has been widely applied to show the response of trees to, most likely, increasing atmospheric $\mathrm{CO}_{2}$ (e.g. Voelker et al. 2006; Wang et al. 2006; Cole et al. 2010). In tropical regions, similar approaches can be applied. So far, two tropical studies have evaluated evidence for increased growth rates, using different approaches. The first study by Rozendaal et al. (2010a) compared diameter growth rates of trees of varying extant diameter for five Bolivian tropical tree species. This approach allowed evaluating whether growth rates of large extant trees further back in time were higher than the recent growth rates of small extant trees in the same diameter class. For four of the five species a historical growth increase was found. Nevertheless, these results need to be interpreted cautiously as they may have been partially caused by sampling biases
(Rozendaal et al. 2010a). Although one cannot rule out some influence of sampling biases in the results, these results are consistent with the expected response to increased atmospheric $\mathrm{CO}_{2}$ (Lloyd and Farquhar 2008) and with the finding in temperate regions that small trees showed stronger growth increases over time than larger trees (Voelker et al. 2006; Wang et al. 2006). The second study by Nock et al. (2010) took a different approach: tree-ring measurements were combined with stable isotope concentrations in the rings. For three tropical tree species from tropical dry forest in Thailand, basal area growth was related to the calendar year using a mixed modelling approach. In this study the opposite pattern was found, as for all species basal area growth decreased in recent years. This growth decline may have been caused by increased water stress from, amongst others, the rise in temperature and a higher frequency of El Niño events (Nock et al. 2010).

\section{Fluctuations in growing conditions and physiological responses: stable isotope levels in tree rings}

Apart from ring width, measurements on the fraction of stable isotopes $\left({ }^{13} \mathrm{C}\right.$ and $\left.{ }^{18} \mathrm{O}\right)$ in tree rings may help reconstructing the physiological responses of tropical trees to climatic variables (McCarroll and Loader 2004). The fraction of ${ }^{13} \mathrm{C}$ in tree rings $\left(\delta^{13} \mathrm{C}\right)$ is determined by discrimination against the heavy ${ }^{13} \mathrm{C}$ isotope in the diffusion and carboxylation of $\mathrm{CO}_{2}$. As drought, light availability and atmospheric $\mathrm{CO}_{2}$ pressure all influence these two physiological processes, the $\delta^{13} \mathrm{C}$ fraction in wood cellulose varies with changes in growing conditions. Information on $\delta^{13} \mathrm{C}$ fractions can be used to estimate changes in water use efficiency or long-term changes in internal $\mathrm{CO}_{2}$ concentration $\left(C_{i}\right)$. For ten tropical tree species long-term trends in stable isotope levels have now been obtained (Hietz et al. 2005; Gebrekirstos et al. 2009; Nock et al. 2010; Brienen et al. 2010b; Gebrekirstos et al. 2010). A decrease in $\delta^{13} \mathrm{C}$ over time was reported, which led to an increase in intrinsic water use efficiency (iWUE) for six species (Hietz et al. 2005; Nock et al. 2010; Brienen et al. 2010b). Cedrela odorata and Swietenia macrophylla from Brazil showed an increase in $C_{i}$ over time, which led to an increase in iWUE of 34 and 52\%, respectively, from 1850 to 1990 (Hietz et al. 2005). Mimosa acantholoba, a Mexican dry forest species, showed a $40 \%$ increase in iWUE over the past 40 years. However, no increase in $C_{i}$ was observed for this species (Brienen et al. 2010b). Nock et al. (2010) showed, similarly, an increase in iWUE for three tropical tree species from Thailand. In contract, growth rates for these species decreased over time (Nock et al. 2010). These studies show that tree species seem to 
Table 1 Persistent differences in growth among trees over subsequent diameter classes
Grey areas indicate a significant rank correlation (Spearman's $\rho$, $P<0.05)$ between the indicated diameter class and the subsequent diameter class. - indicates a non-significant correlation (Spearman's $\rho$, $P>0.05) .+5$ to +35 indicate the distance (in $\mathrm{cm}$ ) to the lower limit of the larger diameter class. For Amburana cearensis, Cedrelinga catenaeformis and Peltogyne cf. heterophylla diameter classes of $10 \mathrm{~cm}$ width were applied, while for the other species classes of $5 \mathrm{~cm}$ width were applied

${ }^{a}$ Brienen et al. (2006)

${ }^{b}$ Brienen et al. (2010c)

c Zuidema et al. (2010)

\begin{tabular}{|c|c|c|c|c|c|c|c|c|}
\hline & $\begin{array}{l}\text { Diameter } \\
(\mathrm{cm})\end{array}$ & +5 & +10 & +15 & +20 & +25 & +30 & +35 \\
\hline Amburana cearensis ${ }^{a}$ & $0-10$ & & - & & - & & - & \\
\hline Cedrelinga catenaeformis $^{\mathrm{a}}$ & $0-10$ & & - & & & & - & \\
\hline Peltogyne cf. heterophylla & $0-10$ & & & & - & & - & \\
\hline $\begin{array}{l}\text { Cedrela odorata (moist } \\
\text { forest) }^{\text {b }}\end{array}$ & $0-5$ & & - & - & - & - & - & - \\
\hline Cedrela odorata (dry forest) ${ }^{b}$ & $0-5$ & & & & & & & \\
\hline Annamocarya sinensis ${ }^{c}$ & $0-5$ & - & - & - & - & - & - & - \\
\hline Calocedrus macrolepis $^{\mathrm{c}}$ & $0-5$ & & - & - & - & - & - & - \\
\hline Dacrydium elatum ${ }^{c}$ & $0-5$ & - & - & - & - & - & - & \\
\hline Pinus kwangtungensis ${ }^{c}$ & $0-5$ & & - & - & - & - & - & - \\
\hline Amburana cearensis ${ }^{\mathrm{a}}$ & $10-20$ & & & & & & & \\
\hline Cedrelinga catenaeformis $^{a}$ & $10-20$ & & & & - & & - & \\
\hline Peltogyne cf. heterophylla & $10-20$ & & & & - & & - & \\
\hline $\begin{array}{l}\text { Cedrela odorata (moist } \\
\text { forest) }^{b}\end{array}$ & $10-15$ & & & & - & - & - & - \\
\hline Cedrela odorata (dry forest) ${ }^{b}$ & $10-15$ & & & & & & & \\
\hline Annamocarya sinensis ${ }^{\mathrm{C}}$ & $10-15$ & & & & & & - & - \\
\hline Calocedrus macrolepis $^{c}$ & $10-15$ & & - & - & - & - & - & - \\
\hline Dacrydium elatum ${ }^{c}$ & $10-15$ & & & & & & & \\
\hline Pinus kwangtungensis ${ }^{c}$ & $10-15$ & & & - & - & - & - & - \\
\hline
\end{tabular}

respond physiologically to increased atmospheric $\mathrm{CO}_{2}$ levels, but that this does not necessarily lead to elevated diameter growth.

Although $\delta^{13} \mathrm{C}$ fractions do respond to water availability (cf. Gebrekirstos et al. 2009; Fichtler et al. 2010), a better approach to detect historical variation in rainfall is the determination of $\delta^{18} \mathrm{O}$. As $\delta^{18} \mathrm{O}$ is not altered by photosynthetic activity, it provides a more direct account of the growing conditions in terms of water availability, although the interpretation of $\delta^{18} \mathrm{O}$ values is not straightforward due to strong interannual and intra-annual fluctuations in $\delta^{18} \mathrm{O}$ in rainfall (cf. McCarroll and Loader 2004). The stronger climatic signal was clearly illustrated in the study of Pons and Helle (this issue) for two tropical tree species. The simultaneous use of $\delta^{13} \mathrm{C}$ and $\delta^{18} \mathrm{O}$ fractions probably represents a powerful approach to use stable isotopes as a tool to understand tree responses to climatic variation and changes (cf. Nock et al. 2010). Such combined measurements allow detecting historical droughts and quantifying their frequency from simultaneous signals of $\delta^{18} \mathrm{O}$ and $\delta^{13} \mathrm{C}$. The longer-term variation (at decadal scale) in $\delta^{13} \mathrm{C}$ and the long-term trends in this isotope can then be interpreted as physiological responses to other drivers (light, $\mathrm{CO}_{2}$ level). 
Forest dynamics: towards a reconstruction of disturbance history

"Where are all the large trees, if this is a virgin tropical forest?". This question was posed by Hartshorn (1978) in a publication on forest turnover in Costa Rica. The study showed that forest turnover was rather fast, ranging from 80 to 138 years in the La Selva area, Costa Rica (Hartshorn 1978). Similar findings were obtained in a tropical forest in French Guiana where $0.64-1.33 \%$ of the canopy was opened through gap formation per year (van der Meer and Bongers 1996). Thus, we may consider tropical forests to be rather dynamic. In temperate forests, tree-ring analysis has been widely applied to reconstruct the disturbance history and historical stand dynamics (e.g. Lorimer and Frelich 1989; Oliver and Larson 1996; Lusk and Smith 1998). By studying growth patterns, in terms of releases, suppressions, and establishment dates of all trees in a certain area, the history of a forest stand can be revealed. Now, as tree-ring analysis starts to be applied also in tropical forests, similar approaches can be used to reconstruct historical stand dynamics. Nevertheless, usually not all species are suitable for tree-ring analysis; thus some adjustments in the methods may be required.

Some tree-ring studies have evaluated historical forest dynamics. Worbes et al. (2003) reconstructed the historical dynamics of a seasonally dry tropical forest in Cameroon in an area of 1 ha, by determining growth rates and ages of trees of nearly all species. The largest trees belonged to long-lived pioneer species, which were usually older than the trees of mature forest species and almost no recruitment of these species was present in the understorey. Mature forest species, in contrast, showed abundant regeneration. In all, the forest was classified as a late secondary forest (Worbes et al. 2003). Similarly, the disturbance history of a seasonal tropical forest in western Thailand was reconstructed by Baker et al. (2005), using a combination of treering analysis and age estimations from growth projections (cf. Baker 2003). The stand structure data of the Huai Kha Khaeng Wildlife Sanctuary showed a single cohort of canopy trees and the simulated age distributions showed that the cohort of canopy trees established in the 1800s and showed that there was a pulse in establishment for the shade-intolerant species in the mid-1900s. Tree-ring analysis provided a more detailed picture: there were peaks in recruitment and growth in the 1910-1920s, 1940-1950s and minor peaks in the late 1800s and 1970s. Tree-ring series of the oldest trees (mostly Afzelia xylocarpa) showed elevated growth in the 1850s. Together, these results indicate that around 1850 a large, widespread disturbance occurred, followed by a few minor disturbances more recently (Baker et al. 2005). A third study on forest dynamics was conducted by Rozendaal et al. (2010b) to assess the frequency of growth releases in a Bolivian moist forest. No trend in release frequency was found over the past 200-300 years. A second method that could reveal changes in forest dynamics-changes in the degree of temporal autocorrelation over time-also did not reveal clear changes over the same period (Rozendaal et al. $2010 b)$. These results show that the occurrence of disturbances at different spatial scales may be important in shaping tropical forest structure and dynamics. Although these are a few isolated studies, the implications of their findings may be far reaching, as they show that current species composition and forest structure can be the result of transient dynamics and past (major) disturbances such as windstorms, droughts or fires. One needs to realize that the current 'state' of tropical forests, in terms of structure and dynamics, may depend strongly on their history (Clark 2007). Tree-ring studies may provide an important contribution to enhance insights into the history of tropical forests, although the interpretation of growth releases in treering series needs to be done cautiously (Soliz-Gamboa 2010), and the sampling design of such studies should probably be adjusted for this aim (Rozendaal et al. 2010b).

Tree-ring analysis may also be useful in enhancing the understanding about secondary forest succession. Secondary forest succession is usually studied in chronosequences, a 'space-for-time' substitution, through comparison of secondary forest stands of different, but known age (e.g. Selaya et al. 2008). Worbes et al. (1992) determined the ages of successional stands in floodplain forests by ring counts of the largest trees, but growth patterns were hardly presented. Similarly, an approach was presented to determine ages of secondary forest stands in Mexico, using treering analysis (Brienen et al. 2009). Annual periodicity of the growth rings could be validated through comparison of ring counts with known stand ages. In the Mexican study, ring counts closely matched stand ages, although pioneer species in older stands may already have disappeared, leading to errors in the reconstruction of stand dynamics (Brienen et al. 2009).

\section{Forest management: how tree rings can help improving timber yield models}

Sustainable forest management requires reliable data to calculate the consequences of various logging regimes for tree populations and future timber availability. Ideally, these growth data should represent the 'lifetime' growth trajectory of a tree, i.e. its growth patterns up to reaching harvestable size. Most growth data from permanent sample plots, however, cover short timespans relative to the lifespan of a tropical tree (cf. Condit 1995). Tree-ring analysis provides a means to do so, and the large advantage of this 
method is that growth rates of the 'successful' trees can be obtained (cf. Rozendaal et al. 2010a).

For a number of commercial tree species, tree-ring analysis has been applied to find that ages of trees at reaching the minimum cutting diameter were high. For example, Pterocarpus angolensis needed on average more than 100 years to reach the minimum cutting diameter of $35 \mathrm{~cm}$ in various sites in deciduous woodlands in tropical southern Africa (Stahle et al. 1999; Therrell et al. 2007). In Cameroon, Triplochiton scleroxylon needed on average 80 years to reach $80 \mathrm{~cm}$ (Worbes et al. 2003). In Central Amazonian white-water floodplain forests large variation in ages at the minimum cutting diameter was observed among commercial tree species: low-wood density species reached the minimum cutting diameter of $50 \mathrm{~cm}$ in an average of 15-67 years, while high-wood density species needed on average 106-151 years (Schöngart 2008). Also in moist forests in the Bolivian Amazon, the timespan needed to reach the minimum cutting diameter was long. Average ages at the minimum cutting diameter for five commercial tree species ranged from 61 to 179 years (Brienen and Zuidema 2006b; Rozendaal et al. 2010c). However, one should take into account that within species ages at the minimum cutting diameter may differ strongly across forest types (da Fonseca et al. 2009). Tabebuia barbata attained the minimum cutting diameter of $50 \mathrm{~cm}$ on average in 117 years in nutrient-rich Amazonian whitewater floodplain forest (várzea), while it took on average 270 years in nutrient-poor black-water floodplain forest (igapó). Similar variation was found for Vatairea guianensis, 70 and 162 years to reach the minimum cutting diameter in the várzea and the igapó, respectively (da Fonseca et al. 2009). Thus, management criteria should not be defined only per species, but the forest type should also be taken into account.

Although ages at the minimum cutting diameter give some idea about long-term growth rates and, thus, the time needed for volume recuperation, growth projections are required. To determine the appropriate minimum cutting diameter and length of the cutting cycle to sustain timber yields, growth trajectories of the individual trees were averaged to derive species-specific long-term growth patterns (Schöngart et al. 2007; Schöngart 2008). In várzea floodplains, the estimated minimum cutting diameter ranged from 47 to $70 \mathrm{~cm}$ for a total of 13 species of different successional status and the estimated cutting cycle varied from 3 to 32 years (Schöngart 2008; da Fonseca et al. 2009). These results illustrate that species-specific management criteria are needed.

However, these studies did not take variation in growth among individual trees into account. Within a species ages at the minimum cutting diameter varied strongly among individuals (e.g. Brienen and Zuidema 2006b; Therrell et al. 2007; Rozendaal et al. 2010c). The incorporation of growth variation among and within individual trees strongly influenced the projected timber volume. Brienen and Zuidema (2006b) applied tree-ring analysis to reconstruct growth rates over the entire lifespan of trees to determine the variation in ages among trees at the moment of attaining the minimum cutting diameter. The observed strength of autocorrelation was incorporated in growth simulation models to be able to simulate tree growth with the same degree of growth variation (cf. Brienen et al. 2006). Harvestable volume for a second cycle in 20 years was much higher, $36-50 \%$ of the harvestable volume at initial harvest, when realistic variation in growth was included for four commercial tree species. Nevertheless, recuperated timber volume at second harvest was low, $18-24 \%$ of initial harvestable volume (Brienen and Zuidema 2007).

Hence, the use of long-term growth data from 'successful' trees, in combination with realistic levels of growth variation included probably provides the most accurate estimations of future timber yield (Rozendaal et al. 2010c). As most slow-growing trees will not make it to the canopy (Landis and Peart 2005; Rozendaal et al. 2010a), average growth rates obtained from trees of all sizes in permanent sample plots likely underestimate longterm growth of trees that eventually reach harvestable size (cf. Sheil 1995; Condit et al. 1995).

\section{Outlook}

Over the past few years, the number of studies in tropical dendroecology has rapidly increased. Significant progress has been made in each of the themes included in this review. Yet, in many of these themes the number of studies is very limited and research has just started to develop. While the few case studies in those themes are valuable in their own right, their limited number does not allow evaluating general patterns. Only for two of the included themes_climate-growth relations and tree ages-quite a number of studies is now available. Climate-growth relations have been published for a large number of tropical tree species as establishing those relations is an often used step in determining the annual character of tree rings. As the annual character of tree rings in the tropics cannot be assumed, many studies evaluate this. Tree ages also have received quite some attention in tropical dendroecology, probably as tree ages are easily obtained and as new data on tree ages provide interesting input in an ongoing discussion about typical tree ages, mortality rates and tree turnover.

What can tree-ring studies contribute to tropical forest ecology? We see two main avenues for further research. 
The first deals with improving our understanding of causes and consequences of growth variation in tropical trees. Tree-ring series show strong temporal variation in growth rates with clear year-to-year variation but also 'plateaus' of lower and higher growth rates. The former can often be related to climatic fluctuations while the latter are thought to be a result of canopy dynamics (gap formation and closure) and stand development patterns. Periods of higher and lower growth (releases and suppressions) are thought to be related to gap formation and closure, but causal relations have not been found. There is a dire need to find out to what extent the decadal-scale variation in growth is indeed related to canopy dynamics. Species-specific relations between light levels and growth rates need to be established to find threshold values for the detection of suppressions and releases in tree-ring data (cf. Baker and Bunyavejchewin 2006). This requires methodological approaches in which light-growth relations are assessed for trees in permanent plots allowing for the interpretation of historical growth variation obtained from tree-ring analysis.

The consequences of growth variation-both temporal, spatial and among individuals-also deserve attention in dendroecological work. Strong temporal growth variation influences year-to-year fluctuations in carbon sequestration of tropical forest trees and causes temporal fluctuations in population dynamics. The occurrence of persistent growth variation among individuals has important consequences for age calculations, tree population dynamics and the calculation of timber volume recuperation. Such consequences are poorly understood at this moment, although their implications may be large.

Studying causes and consequences of growth variation requires a different sampling strategy than often adopted in dendrochronological studies. Traditionally, tree-ring studies included small samples of preferably adult trees, from which only those ring series with high interseries correlations are selected, often without dealing with juvenile growth rings. For ecological studies often much larger sample sizes are required (minimally 50-80 trees per species) in which juvenile trees are also represented, as well as individuals of which temporal growth variation does not (strongly) correlate to that of the others.

A second avenue of dendroecological research that we consider to be important deals with the detection of climate change impacts on tree growth. Given the important role of tropical forests in the global carbon cycle, it is evident that the responses of tropical trees to atmospheric changes need to be unravelled (Baker 2010). Physiological, dendroecological and dendroclimatological studies can assist in providing much-needed insights into the physiological responses of trees to climatic variation. Although climategrowth relations have now been established for quite a number of species, the mechanisms by which multiple atmospheric changes affect tree growth are poorly understood. The combination of tree-ring analysis with determination of stable isotopes $\left({ }^{13} \mathrm{C}\right.$ and $\left.{ }^{18} \mathrm{O}\right)$ is a promising approach to unravel the drivers of climate-growth relations (cf. Nock et al. 2010). In addition, novel wood anatomical approaches may provide a way forward in understanding and predicting responses of trees to climatic changes (cf. Fonti et al. 2010).

Tree-ring analysis in the tropics provides the muchneeded long-term data on tree growth and tree recruitment. More widespread application of rigorous dendroecological studies will yield important insights into the mechanisms that govern tree growth and forest dynamics in tropical forests. Such knowledge is highly valuable in assessing how tropical forests will respond to the predicted climatic changes.

Acknowledgments We acknowledge Patrick Baker, Charles Nock, Pham Duc Chien and Mart Vlam for contributing unpublished data. We thank Patrick Baker and two anonymous reviewers for insightful comments on an earlier version of the manuscript. DMAR was supported by grant W 84-608 from the Netherlands Organisation for Scientific Research (NWO). PAZ was supported by ERC grant 242955 from the European Research Council.

Open Access This article is distributed under the terms of the Creative Commons Attribution Noncommercial License which permits any noncommercial use, distribution, and reproduction in any medium, provided the original author(s) and source are credited.

\section{References}

Anchukaitis KJ, Evans MN, Wheelwright NT, Schrag DP (2008) Stable isotope chronology and climate signal calibration in neotropical montane cloud forest trees. J Geophys Res 113:G03030. doi:10.1029/2007JG000613

Ashton PS (1981) The need for information regarding tree age and growth in tropical forests. In: Bormann FH, Berlyn G (eds) Age and growth rate of tropical trees; new directions for research. Yale University, School of Forestry and Environmental Studies. Bulletin No. 94, pp 3-6

Baker PJ (2003) Tree age estimation for the tropics: a test from the southern Appalachians. Ecol Appl 13:1718-1732

Baker PJ (2010) Changing juvenile growth patterns in tropical trees: selective effects, history, or both? New Phytol 185:595-598

Baker PJ, Bunyavejchewin S (2006) Suppression, release and canopy recruitment in five tree species from a seasonal tropical forest in western Thailand. J Trop Ecol 22:521-529

Baker PJ, Bunyavejchewin S, Oliver CD, Ashton PS (2005) Disturbance history and historical stand dynamics of a seasonal tropical forest in western Thailand. Ecol Monogr 75:317-343

Baker PJ, Palmer JG, D'Arrigo R (2008) The dendrochronology of Callitris intratropica in northern Australia: annual ring structure, chronology development and climate correlations. Aust J Bot 56:311-320

Bräuning A, Volland-Voigt F, Burchardt I, Ganzhi O, Nauss T, Peters T (2009) Climatic control of radial growth of Cedrela montana in a humid mountain rainforest in southern Ecuador. Erdkunde 63:337-345 
Brienen RJW, Zuidema PA (2005) Relating tree growth to rainfall in Bolivian rain forests: a test for six species using tree ring analysis. Oecologia 146:1-12

Brienen RJW, Zuidema PA (2006a) Lifetime growth patterns and ages of Bolivian rain forest trees obtained by tree ring analysis. J Ecol 94:481-493

Brienen RJW, Zuidema PA (2006b) The use of tree rings in tropical forest management: projecting timber yields of four Bolivian tree species. For Ecol Manage 226:256-267

Brienen RJW, Zuidema PA (2007) Incorporating persistent tree growth differences increases estimates of tropical timber yield. Front Ecol Environ 5:302-306

Brienen RJW, Zuidema PA, During HJ (2006) Autocorrelated growth of tropical forest trees: unraveling patterns and quantifying consequences. For Ecol Manage 237:179-190

Brienen RJW, Lebrija-Trejos E, van Breugel M, Pérez-García EA, Bongers F, Meave JA, Martínez-Ramos M (2009) The potential of tree rings for the study of forest succession in southern Mexico. Biotropica 41:186-195

Brienen RJW, Lebrija-Trejos E, Zuidema PA, Martínez-Ramos M (2010a) Climate-growth analysis for a Mexican dry forest tree shows strong impact of sea surface temperatures and predicts future growth declines. Glob Change Biol 16:2001-2012

Brienen RJW, Wanek W, Hietz P (2010b) Stable carbon isotopes in tree rings indicate improved water use efficiency and drought responses of a tropical dry forest tree species. Trees-Struct Funct. doi:10.1007/s00468-010-0474-1

Brienen RJW, Zuidema PA, Martínez-Ramos M (2010c) Attaining the canopy in dry and moist tropical forests: strong differences in tree growth trajectories reflect variation in growing conditions. Oecologia 163:485-496

Buckley BM, Duangsathaporn K, Palakit K, Butler S, Syhapanya V, Xaybouangeun N (2007) Analyses of growth rings of Pinus merkusii from Lao PDR. For Ecol Manage 253:120-127

Chambers JQ, Higuchi N, Schimel JP (1998) Ancient trees in Amazonia. Nature 39:135-136

Chave J, Condit R, Muller-Landau HC, Thomas SC et al (2008) Assessing evidence for a pervasive alteration in tropical tree communities. Plos Biol 6:455-462

Chazdon RL, Fetcher N (1984) Light environments of tropical forests. In: Medina E, Mooney HA, Vasques-Yanes C (eds) Physiological ecology of plants of the wet tropics. W. Junk, The Hague, the Netherlands, pp 27-36

Chien PD (2006) Demography of threatened tree species in Vietnam. $\mathrm{PhD}$ thesis, Utrecht University, Utrecht, The Netherlands

Chowdhury MQ, Schmitz N, Verheyden A, Sass-Klaassen U, Koedam N, Beeckman H (2008) Nature and periodicity of growth rings in two Bangladeshi mangrove species. IAWA J 29:265-276

Clark DA (2007) Detecting tropical forests' responses to global climatic and atmospheric change: current challenges and a way forward. Biotropica 39:4-19

Clark DA, Clark DB (1992) Life-history diversity of canopy and emergent trees in a neotropical rain-forest. Ecol Monogr 62:315-344

Cole CT, Anderson JE, Lindroth RL, Waller DM (2010) Rising concentrations of atmospheric $\mathrm{CO}_{2}$ have increased growth in natural stands of quaking aspen (Populus tremuloides). Glob Change Biol 16:2186-2197

Condit R (1995) Research in large, long-term tropical forest plots. Trends Ecol Evol 10:18-22

Condit R, Hubbel SP, Foster RB (1995) Demography and harvest potential of Latin American timber species: data from a large, permanent plot in Panama. J Trop For Sci 7:599-622
Cook ER, Anchukaitis KJ, Buckley BM, D'Arrigo RD, Jacoby GC, Wright WE (2010) Asian monsoon failure and megadrought during the last millennium. Science 328:486-489

Coster C (1927) Zur Anatomie und Physiologie der Zuwachszonen und Jahresbildung in den Tropen. Annales du Jardin Botanique de Buitenzorg 37:49-160

Couralet C, Sass-Klaassen U, Sterck F, Bekele T, Zuidema PA (2005) Combining dendrochronology and matrix modelling in demographic studies: an evaluation for Juniperus procera in Ethiopia. For Ecol Manage 216:317-330

Couralet C, Sterck FJ, Sass-Klaassen U, van Acker J, Beeckman H (2010) Species-specific growth responses to climate variations in understory trees of a central African rain forest. Biotropica 42:503-511

da Fonseca SF, Piedade MTF, Schöngart J (2009) Wood growth of Tabebuia barbata (E. Mey.) Sandwith (Bignoniaceae) and Vatairea guianensis Aubl. (Fabaceae) in Central Amazonian black-water (igapó) and white-water (várzea) floodplain forests. Trees-Struct Funct 23:127-134

Dezzeo N, Worbes M, Ishii I, Herrera R (2003) Annual tree rings revealed by radiocarbon dating in seasonally flooded forest of the Mapire River, a tributary of the lower Orinoco River, Venezuela. Plant Ecol 168:165-175

Dünisch O, Montoia VR, Bauch J (2003) Dendroecological investigations on Swietenia macrophylla King and Cedrela odorata L.(Meliaceae) in the central Amazon. Trees-Struct Funct 17:244-250

Enquist BJ, Leffler AJ (2001) Long-term tree ring chronologies from sympatric tropical dry-forest trees: individualistic responses to climatic variation. J Trop Ecol 17:41-60

Enright NJ, Hartshorn GS (1981) The demography of tree species in undisturbed tropical rainforest. In: Bormann FH, Berlyn G (eds) Age and growth rate of tropical trees; new directions for research. Yale University, School of Forestry and Environmental Studies. Bulletin No. 94, pp 107-119

Fichtler E, Clark DA, Worbes M (2003) Age and long-term growth of trees in an old-growth tropical rain forest, based on analyses of tree rings and C-14. Biotropica 35:306-317

Fichtler E, Trouet V, Beeckman H, Coppin P, Worbes M (2004) Climatic signals in tree rings of Burkea africana and Pterocarpus angolensis from semiarid forests in Namibia. Trees 18:442-451

Fichtler E, Helle G, Worbes M (2010) Stable-carbon isotope time series from tropical tree rings indicate a precipitation signal. Tree-Ring Res 66:35-49

Fonti P, von Arx G, Garcia-Gonzalez I, Eilmann B, Sass-Klaassen U, Gartner H, Eckstein D (2010) Studying global change through investigation of the plastic responses of xylem anatomy in tree rings. New Phytol 185:42-53

Gebrekirstos A, Mitlöhner R, Teketay D, Worbes M (2008) Climategrowth relationships of the dominant tree species from semi-arid savanna woodland in Ethiopia. Trees-Struct Funct 22:631-641

Gebrekirstos A, Worbes M, Teketay D, Fetene M, Mitlöhner R (2009) Stable carbon isotope ratios in tree rings of co-occurring species from semi-arid tropics in Africa: patterns and climatic signals. Glob Planet Change 66:253-260

Gebrekirstos A, van Noordwijk M, Neufeldt H, Mitlöhner R (2010) Relationships of stable carbon isotopes, plant water potential and growth: an approach to asses water use efficiency and growth strategies of dry land Agroforestry species. Trees-Struct Funct. doi:10.1007/s00468-010-0467-0

Grogan J, Landis RM (2009) Growth history and crown vine coverage are principal factors influencing growth and mortality rates of big-leaf mahogany Swietenia macrophylla in Brazil. J Appl Ecol 46:1283-1291 
Hartshorn GS (1978) Tree falls and tropical forest dynamics. In: Tomlinson PB, Zimmermann MH (eds) Tropical trees as living systems. Cambridge University Press, Cambridge, pp 617-638

Hietz P, Wanek W, Dünisch O (2005) Long-term trends in cellulose delta C-13 and water-use efficiency of tropical Cedrela and Swietenia from Brazil. Tree Physiol 25:745-752

Hua Q, Barbetti M, Worbes M, Head J, Levchenko VA (1999) Review of radiocarbon data from atmospheric and tree ring samples for the period 1945-1997 AD. IAWA J 20:261-283

Kammesheidt L, Dagang AA, Schwarzwaller W, Weidelt HJ (2003) Growth patterns of dipterocarps in treated and untreated plots. For Ecol Manage 174:437-445

Krepkowski J, Bräuning A, Gebrekirstos A, Strobl S (2010) Seasonal growth dynamics and climatic control of different tree life forms in tropical mountain forest in Ethiopia. Trees-Struct Funct. doi: 10.1007/s00468-010-460-7

Kurokawa H, Yoshida T, Nakamura T, Lai J, Nakashizuka T (2003) The age of tropical rain-forest canopy species, Borneo ironwood (Eusideroxylon zwageri), determined by ${ }^{14} \mathrm{C}$ dating. J Trop Ecol 19:1-7

Landis RM, Peart DR (2005) Early performance predicts canopy attainment across life histories in subalpine forest trees. Ecology 86:63-72

Laurance WF, Nascimento HEM, Laurance SG, Condit R, D'Angelo $S$, Andrade A (2004) Inferred longevity of Amazonian rainforest trees based on a long-term demographic study. For Ecol Manage 190:131-143

Lewis SL, Malhi Y, Phillips OL (2004) Fingerprinting the impacts of global change on tropical forests. Philos Trans R Soc Lond Ser B-Biol Sci 359:437-462

Lewis SL, Lloyd J, Sitch S, Mitchard ETA, Laurance WF (2009) Changing ecology of tropical forests: evidence and drivers. Annu Rev Ecol Evol Syst 40:529-549

Lieberman D, Lieberman M, Hartshorn GS, Peralta R (1985) Growth rates and age-size relationships of tropical wet forest trees in Costa Rica. J Trop Ecol 1:97-109

Lisi CS, Tomazello M, Botosso PC, Roig FA, Maria VRB, FerreiraFedele L, Voigt ARA (2008) Tree-ring formation, radial increment periodicity, and phenology of tree species from a seasonal semi-deciduous forest in southeast Brazil. IAWA J 29:189-207

Lloyd J, Farquhar GD (2008) Effects of rising temperatures and $\left[\mathrm{CO}_{2}\right]$ on the physiology of tropical forest trees. Philos Trans R Soc Lond Ser B-Biol Sci 363:1811-1817

Lorimer CG, Frelich LE (1989) A methodology for estimating canopy disturbance frequency and intensity in dense temperate forests. Can J For Res 19:651-663

Lusk CH, Smith B (1998) Life history differences and tree species coexistence in an old-growth New Zealand rain forest. Ecology 79:795-806

Martínez-Ramos M, Alvarez-Buylla ER (1998) How old are tropical rain forest trees? Trends Plant Sci 3:400-405

McCarroll D, Loader NJ (2004) Stable isotopes in tree rings. Quaternary Sci Rev 23:771-801

Metcalf CJ, Horvitz CC, Tuljapurkar S, Clark DA (2009) A time to grow and a time to die: a new way to analyze the dynamics of size, light, age, and death of tropical trees. Ecology 90:2766-2778

Nock CA, Baker PJ, Wanek W, Leis A, Grabner M, Bunyavejchewin S, Hietz P (2010) Long-term increases in intrinsic water-use efficiency do not lead to increased stem growth in a tropical monsoon forest in western Thailand. Glob Change Biol. doi: 10.1111/j.1365-2486.2010.02222.x

Ohashi S, Okada N, Nobuchi T, Siripatanadilok S, Veenin T (2009) Detecting invisible growth rings of trees in seasonally dry forests in Thailand: isotopic and wood anatomical approaches. TreesStruct Funct 23:813-822

Oliver CD, Larson BC (1996) Forest stand dynamics. Wiley, New York

Pons TL, Helle G (this issue) Identification of anatomically nondistinct annual rings in tropical trees using stable isotopes. TreesStruct Funct

Poussart PF, Evans MN, Schrag DP (2004) Resolving seasonality in tropical trees: multi-decade, high-resolution oxygen and carbon isotope records from Indonesia and Thailand. Earth Planet Sci Lett 218:301-316

Priya PB, Bhat KM (1998) False ring formation in teak (Tectona grandis Lf) and the influence of environmental factors. For Ecol Manage 108:215-222

Pumijumnong N, Eckstein D, Sass U (1995) Tree-ring research on Tectona grandis on northern Thailand. IAWA J 16:385-392

Robert EMR, Schmitz N, Okello JA, Boeren I, Beeckman H, Koedam $\mathrm{N}$ (this issue) Mangrove growth rings: fact or fiction? TreesStruct Funct

Rodríguez R, Mabres A, Luckman B, Evans M, Masiokas M, Ektvedt TM (2005) "El Niño" events recorded in dry-forest species of the lowlands of northwest Peru. Dendrochronologia 22:181-186

Rozendaal DMA (2010) Looking backwards: using tree rings to evaluate long-term growth patterns of Bolivian forest trees. PROMAB Scientific Series 12. PhD thesis, Utrecht University, Utrecht, The Netherlands

Rozendaal DMA, Brienen RJW, Soliz-Gamboa CC, Zuidema PA (2010a) Tropical tree rings reveal preferential survival of fastgrowing juveniles and increased juvenile growth rates over time. New Phytol 185:759-769

Rozendaal DMA, Soliz-Gamboa CC, Zuidema PA (2010b) Assessing long-term changes in tropical forest dynamics: a first test using tree-ring analysis. Trees-Struct Funct. doi:10.1007/s00468010-0478-x

Rozendaal DMA, Soliz-Gamboa CC, Zuidema PA (2010c) Timber yield projections for tropical tree species: the influence of fast juvenile growth on timber volume recovery. For Ecol Manage 259:2292-2300

Sass-Klaassen U, Couralet C, Sahle Y, Sterck FJ (2008) Juniper from Ethiopia contains a large-scale precipitation signal. Int J Plant Sci 169:1057-1065

Schöngart J (2008) Growth-Oriented Logging (GOL): a new concept towards sustainable forest management in Central Amazonian várzea floodplains. For Ecol Manage 256:46-58

Schöngart J, Piedade MTF, Ludwigshausen S, Worbes M (2002) Phenology and stem-growth periodicity of tree species in Amazonian floodplain forests. J Trop Ecol 18:1-17

Schöngart J, Junk WJ, Piedade MTF, Ayres JM, Huttermann A, Worbes M (2004) Teleconnection between tree growth in the Amazonian floodplains and the El Niño-Southern Oscillation effect. Glob Change Biol 10:683-692

Schöngart J, Piedade MTF, Wittmann F, Junk WJ, Worbes M (2005) Wood growth patterns of Macrolobium acaciifolium (Benth.) Benth. (Fabaceae) in Amazonian black-water and white-water floodplain forests. Oecologia 145:454-461

Schöngart J, Orthmann B, Hennenberg KJ, Porembski S, Worbes M (2006) Climate-growth relationships of tropical tree species in West Africa and their potential for climate reconstruction. Glob Change Biol 12:1139-1150

Schöngart J, Wittmann F, Worbes M, Piedade MTF, Krambeck HJ, Junk WJ (2007) Management criteria for Ficus insipida Willd. (Moraceae) in Amazonian white-water floodplain forests defined by tree-ring analysis. Ann For Sci 64:657-664

Selaya NG, Oomen RJ, Netten JJC, Werger MJA, Anten NPR (2008) Biomass allocation and leaf life span in relation to light 
interception by tropical forest plants during the first years of secondary succession. J Ecol 96:1211-1221

Sheil D (1995) A critique of permanent plot methods and analysis with examples from Budongo-forest, Uganda. For Ecol Manage 77:11-34

Soliz-Gamboa CC (2010) Shedding light on tree growth: ring analysis of juvenile tropical trees. PROMAB Scientific Series 13. PhD thesis, Utrecht University, Utrecht, The Netherlands

Soliz-Gamboa CC, Rozendaal DMA, Ceccantini G, Angyalossy V, van der Borg K, Zuidema PA (2010) Evaluating the annual nature of juvenile rings in Bolivian tropical rainforest trees. Trees-Struct Funct. doi:10.1007/s00468-010-0468-z

Stahle DW, Mushove PT, Cleaveland MK, Roig FA, Haynes GA (1999) Management implications of annual growth rings in Pterocarpus angolensis from Zimbabwe. For Ecol Manage 124:217-229

Therrell MD, Stahle DW, Ries LP, Shugart HH (2006) Tree-ring reconstructed rainfall variability in Zimbabwe. Clim Dyn 26:677-685

Therrell MD, Stahle DW, Mukelabai MA, Shugart HH (2007) Age, and radial growth dynamics of Pterocarpus angolensis in southern Africa. For Ecol Manage 244:24-31

Trouet V, Haneca K, Coppin P, Beeckman H (2001) Tree ring analysis of Brachystegia spiciformis and Isoberlinia tomentosa: evaluation of the enso-signal in the miombo woodland of eastern Africa. IAWA J 22:385-399

Trouet V, Coppin P, Beeckman H (2006) Annual growth ring patterns in Brachystegia spiciformis reveal influence of precipitation on tree growth. Biotropica 38:375-382

Turner IM (2001) The ecology of trees in the tropical rainforest. Cambridge University Press, New York

van der Meer PJ, Bongers F (1996) Formation and closure of canopy gaps in the rain forest at Nouragues, French Guiana. Vegetatio 126:167-179

Verheyden A, Kairo JG, Beeckman H, Koedam N (2004) Growth rings, growth ring formation and age determination in the mangrove Rhizophora mucronata. Ann Bot 94:59-66

Verheyden A, De Ridder F, Schmitz N, Beeckman H, Koedam N (2005) High-resolution time series of vessel density in Kenyan mangrove trees reveal a link with climate. New Phytol 167:425-435

Voelker SL, Muzika RM, Guyette RP, Stambaugh MC (2006) Historical $\mathrm{CO}_{2}$ growth enhancement declines with age in Quercus and Pinus. Ecol Monogr 76:549-564

Volland-Voigt F, Bräuning A, Ganzhi O, Peters T, Maza H (2010) Radial stem variations of Tabebuia chrysantha (Bignoniaceae) in different tropical forest ecosystems of southern Ecuador. TreesStruct Funct. doi:10.1007/s00468-010-0461-6
Wang GG, Chhin S, Bauerle WL (2006) Effect of natural atmospheric $\mathrm{CO} 2$ fertilization suggested by open-grown white spruce in a dry environment. Glob Change Biol 12:601-610

Williamson GB, Eldik Tv, Delamonica P, Laurance WF (1999) How many millenarians in Amazonia? Sizing the ages of large trees. Trends Plant Sci 4:387

Wils THG, Robertson I, Eshetu Z, Sass-Klaassen UGW, Koprowski M (2009) Periodicity of growth rings in Juniperus procera from Ethiopia inferred from crossdating and radiocarbon dating. Dendrochronologia 27:45-58

Wils THG, Robertson I, Eshetu Z, Touchan R, Sass-Klaassen U, Koprowski M (2010) Crossdating Juniperus procera from North Gondar, Ethiopia. Trees-Struct Funct. doi:10.1007/s00468010-0475-0

Worbes M (1999) Annual growth rings, rainfall-dependent growth and long-term growth patterns of tropical trees from the Caparo Forest Reserve in Venezuela. J Ecol 87:391-403

Worbes M (2002) One hundred years of tree-ring research in the tropics: a brief history and an outlook to future challenges. Dendrochronologia 20:217-231

Worbes M, Junk WJ (1989) Dating tropical trees by means of C-14 from bomb tests. Ecology 70:503-507

Worbes M, Junk WJ (1999) How old are tropical trees? The persistence of a myth. IAWA J 20:255-260

Worbes M, Klinge H, Revilla JD, Martius C (1992) On the dynamics, floristic subdivision, and geographical distribution of várzea forests in Central Amazonia. J Veg Sci 3:553-564

Worbes M, Staschel R, Roloff A, Junk WJ (2003) Tree ring analysis reveals age structure, dynamics and wood production of a natural forest stand in Cameroon. For Ecol Manage 173:105-123

Wright SJ (2005) Tropical forests in a changing environment. Trends Ecol Evol 20:553-560

Wyckoff PH, Clark JS (2002) The relation between growth and mortality for seven co-occurring tree species in the southern Appalachian Mountains. J Ecol 90:604-615

Zimmer H, Baker P (2009) Climate and historical stand dynamics in the tropical pine forests of northern Thailand. For Ecol Manage 257:190-198

Zuidema PA, Brienen RJW, During HJ, Güneralp B (2009) Do persistently fast-growing juveniles contribute disproportionately to population growth? A new analysis tool for matrix models and its application to rainforest trees. Am Nat 174:709-719

Zuidema PA, Vlam M, Chien PD (2010) Ages and long-term growth patterns of four threatened Vietnamese tree species. Trees-Struct Funct. doi:10.1007/s00468-010-0473-2 